\title{
PRE-IRRIGATION WITH GEL HIDRORETENTOR IN EUCALYPTUS SEEDLING ESTABLISHMENT IN THE FIELD
}

\author{
Lynniker Trés Bernardino ${ }^{1}$, Robson Bonomo ${ }^{1}$, Joabe Martins de Souza ${ }^{1 *}$, Moises Zucoloto ${ }^{2}$ \\ ${ }^{1}$ Federal University of Espirito Santo - University Center North of Espírito Santo campus (UFES-CEUNES), Postgraduate Program in \\ Tropical Agriculture, Sao Mateus-ES, Brazil - e-mail: lynnikert@hotmail.com, robson.bonomo@ufes.br, joabenv@gmail.com* \\ ${ }^{2}$ Federal University of Espirito Santo - Center of Agrarian Sciences and Engineering campus (UFES-CCAE), Department of Agronomy, \\ Alegre-ES, Brazil - e-mail:moises.zucoloto@ufes.br
}

Received for publication: 08/11/2017 - Accepted for publication: 06/12/2018

\begin{abstract}
Resumo
Pré-irrigação com gel hidroretentor no estabelecimento de mudas de eucalipto no campo. As pesquisas têm buscado novas tecnologias visando estabelecer florestas mais produtivas. O gel hidroretentor tem função de aumentar a disponibilidade de água para a planta, na fase mais crítica do estabelecimento da muda no campo. Objetivou-se avaliar doses crescentes de gel hidroretentor aplicados em pré-irrigação, momentos antes do plantio, observando o índice de sobrevivência e as variáveis morfológicas para o híbrido Eucalyptus grandis $\mathrm{x}$ E. urophylla - 03, em Chapadinha-MA. O experimento foi em blocos casualizados, com sete tratamentos e três repetições. Os tratamentos foram constituídos de cinco doses crescentes 1,0;2,0; 3,0; 4,0 e 5,0 g $5 \mathrm{~L}^{-1}$ de solução gel por litros de água na pré-irrigação, um tratamento sem a utilização do gel; e um tratamento com plantio convencional. O uso da pré-irrigação, com polímeros hidroretentores, conhecidos como gel hidroretentor, na concentração de 4 e $5 \mathrm{~g} 5 \mathrm{~L}^{-1}$, propicia maior altura e diâmetro de caule, potencializando o crescimento das mudas de eucalipto em pós-plantio. A profundidade do sistema radicular não obteve melhorias quando utilizado dose superior de gel, obtendo valores menores do que nos tratamentos sem a utilização do gel hidroretentor. Palavras-chave: Polímero hidroretentor, Eucalyptus spp., lâminas de irrigação, qualidade de mudas.
\end{abstract}

\begin{abstract}
Research has sought new technologies aimed at establishing more productive forests. Hidroretentor gel that has the function of increasing the availability of water to the plant, in the most critical stage of establishment of the cuttings in the field. The objective of this study was to evaluate increasing levels of water retention gel applied in pre-irrigation, moments before planting, observing the survival index, and the morphological variables for the hybrid Eucalyptus grandis $\mathrm{x}$ E. urophylla-03, in Chapadinha-MA. The experiment was a randomized block with seven treatments and three replicates. The treatments consisted of five increasing doses of 1.0; 2.0; 3.0;

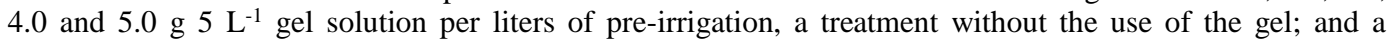
conventional planting treatment. The use of pre-irrigation with hidroretentores polymers, known as hidroretentor gel at a concentration of 4 and $5 \mathrm{~g} 5 \mathrm{~L}^{-1}$, provides a greater height, stem diameter, increasing the growth of eucalyptus plants in post-planting. The depth of the root system did not improve when a higher dose of gel was used, obtaining lower values than those obtained by the treatment without the use of the hidroretentor gel.

Keywords: Polymer hidroretentor, Eucalyptus spp, irrigation depths, cuttings quality.
\end{abstract}

\section{INTRODUCTION}

Species of the genus Eucalyptus have shown great potential, considering the versatility of wood use for numerous applications, mainly for industrial purposes, causing several companies to seek to improve their breeding programs, ensuring the establishment of highly productive plantations (SOUZA; PERES, 2016).

The availability of water for the development of plants is a fundamental and determinant factor, since scarcity or excess affects the growth of plants. In tree seedlings, irrigation during planting and after the first weeks is of recognized importance in commercial plantations, especially in times when climatic conditions are not favorable to establishment and development (BUZETTO et al., 2002).

FLORESTA, Curitiba, PR, v. 49, n. 3, p. 391-400, jul/set 2019.

Bernardino, L. T. et.al.

ISSN eletrônico 1982-4688

DOI: $10.5380 /$ rf.v49 i3.56245 
In forestry, forest management is constantly seeking new technologies that reduce the operational costs of each activity and, in addition, raise productivity and promote biological balance in ecosystems. Among the available technologies for the supply of water to plants, soil conditioners, also known as hidroretentor polymers and water-repellent gels, and as a hydrogel, which, although a generic term and used in several areas, have been widely used in agriculture. Their use provides improved chemical and physical characteristics of the substrate, particularly the attributes responsible for the storage and availability of water to plants, moreover, its use provides a lower percolation and leaching of nutrients in the soil, avoiding losses and providing better availability nutrients for plants (FERREIRA et al., 2014; NAVROSKI et al., 2016).

In order to make the most of the hydrogel characteristics, an alternative is the use of the same in the irrigation that precedes the planting of the seedlings for the field (pre-irrigation), characterized by the application of the irrigation water together with a dose of hydrogel. But like all technology, the use of hidroretentores this step, when performed incorrectly can harm the development of plants, being necessary to the determination of some factors to assist in decision making, such as the dosage to be applied; the phases of the crop in which there is response; the form of application; and, the modifications in the handling.

In a study by Nicoletti et al. (2014), with different doses of hydrogel, verified that the presence of hydrogel, even in the lowest dosage tested, was efficient at the rooting of Eucalyptus urograndis cuttings. In addition to increasing rooting of the cuttings, the hydrogel seedlings showed a larger green and dry mass of the aerial part and greater weight of roots. Considering the costs of the hydrogel and the results obtained, the use of the lowest dosage $\left(1.0 \mathrm{~g} \mathrm{~kg}^{-1}\right)$ may be recommended.

Therefore, the objective of this work was to evaluate increasing doses of hidroretentor gel applied in preirrigation, observing the survival index and morphological parameters of the hybrid Eucalyptus grandis $\mathrm{x}$ E. urophylla-03.

\section{MATERIAL AND METHODS}

The experiment was conducted in a commercial planted area of the hybrid Eucalyptus grandis $\mathrm{x} E$. urophylla- 03, in the municipality of Chapadinha, state of Maranhão, at coordinates $3^{\circ} 44^{\prime \prime} 26^{\prime} \mathrm{S}$ and $43^{\circ} 21^{\prime \prime} 33^{\prime} \mathrm{O}$, and altitude of $93 \mathrm{~m}$. The region's climate is classified according to Köppen (1936) as tropical (Aw), characterized by a dry season of winter (average temperature higher than $27^{\circ} \mathrm{C}$ ) with tendency to rainfall concentration in the summer, and annual precipitation of 1,670 $\mathrm{mm}$.

The monthly meteorological data, corresponding to the planting periods of the seedlings in the field until the last evaluation, 180 days after planting (Figure 1), were collected at INMET's Chapadinha meteorological station, located eight kilometers from the experimental area.

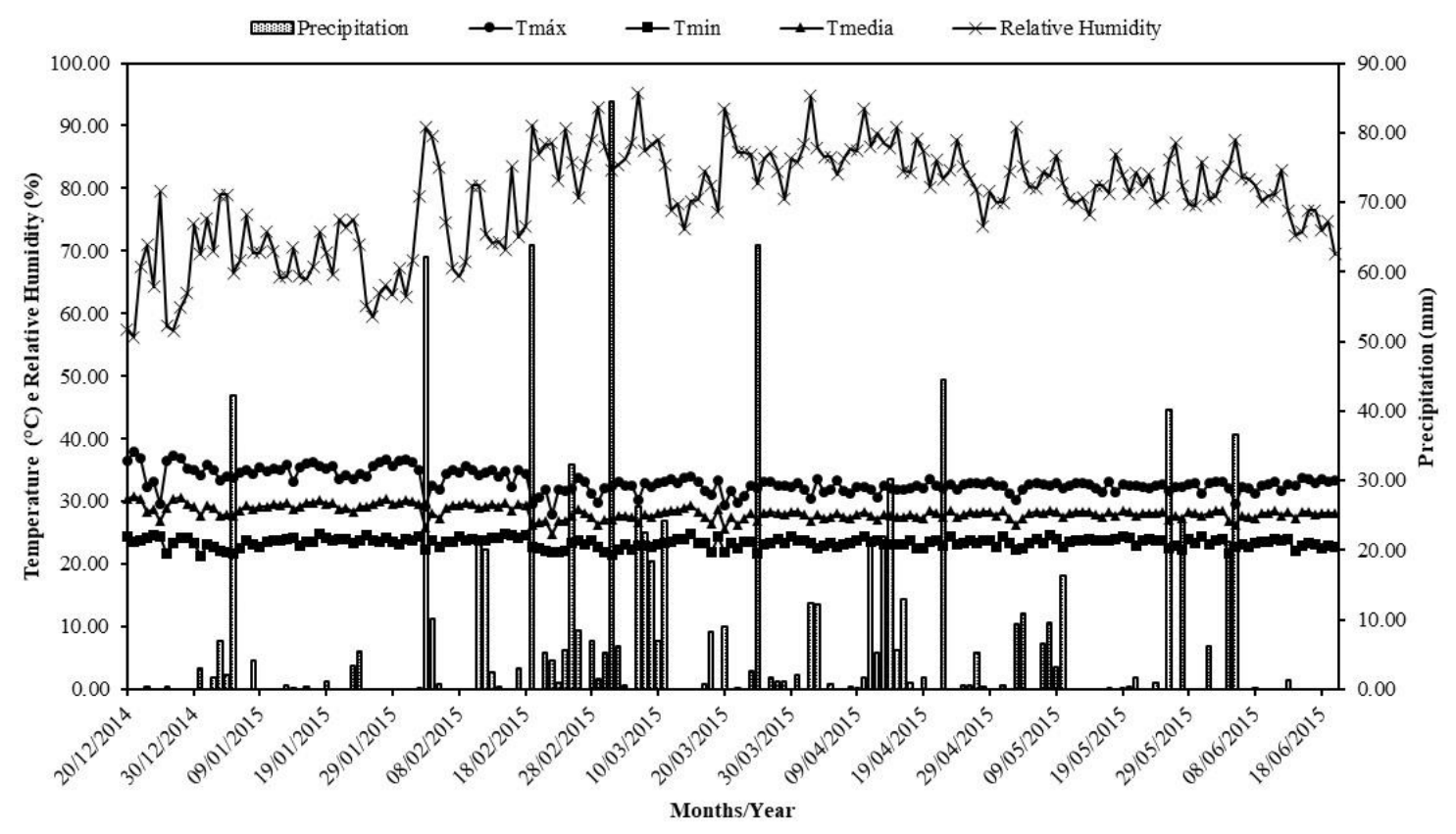

FLORESTA, Curitiba, PR, v. 49, n. 3, p. 391 - 400, jul/set 2019 Bernardino, L. T. et.al. 
Figure 1. Daily precipitation; maximum (Tmax), minimum (Tmin) and medium temperatures (Tmedia); and relative humidity during the experimental period. Chapadinha-MA.

Figura 1. Precipitação diária; temperaturas do ar máxima (Tmáx), mínima (Tmin) e média (Tmédia); e, umidade relativa média do ar, durante o período experimental. Chapadinha-MA.

The soil of the experimental area is classified as Yellow Latosol, with sandy soils on the surface horizon. Soils with these characteristics are generally found in areas with pronounced dry, semi-arid or basal or limestone seasons (EMBRAPA, 2013). It is noteworthy that they are typical soils of equatorial and tropical regions. The granulometric characterization of the soil is expressed in Table 1.

Table 1. Granulometric characterization of soil layers in the study area in Chapadinha, MA.

Tabela 1. Caracterização granulométrica das camadas do solo na área de estudo em Chapadinha, MA.

\begin{tabular}{cccccc}
\hline $\begin{array}{c}\text { Layers } \\
(\mathbf{m})\end{array}$ & $\begin{array}{c}\text { AG } \\
(\boldsymbol{\%})\end{array}$ & $\begin{array}{c}\text { AF } \\
(\boldsymbol{\%})\end{array}$ & $\begin{array}{c}\text { Silt } \\
(\boldsymbol{\%})\end{array}$ & $\begin{array}{c}\text { Clay } \\
(\boldsymbol{\%})\end{array}$ & Textural Class \\
\hline $0.00-0.20$ & 22.38 & 61.68 & 9.77 & 6.17 & Sand \\
$0.20-0.40$ & 20.97 & 57.44 & 10.35 & 11.24 & Loam Sandy \\
$0.40-0.60$ & 18.64 & 55.64 & 11.58 & 14.14 & Loam Sandy \\
$0.60-1.00$ & 16.45 & 46.62 & 10.37 & 26.56 & Sandy Loam \\
\hline
\end{tabular}

In what: $\mathrm{AG}=$ Coarse Sand; $\mathrm{AF}=$ Fine Sand

The seedlings were produced from minicuttings, varying between 8 and $12 \mathrm{~cm}$, taken from the intermediate position in the budding of the minicepas, the mini clonal garden. The commercial clone Eucalyptus grandis $\mathrm{x}$ E. urophylla-03 was used in the experiment because this genetic material is the most cultivated in the region.

For the cultivation of the seedlings, a polypropylene tube was used, with a volume capacity of $53 \mathrm{~cm}^{3}$, with four striae. The substrate was composed of $40 \%$ composted eucalyptus peel $+30 \%$ fine type expanded vermiculite $+30 \%$ charcoal rice husk. When substrate was added $2.0 \mathrm{~kg} \mathrm{~m}^{-3}$ the Osmocote® (19-06-10) slow release microgranules $+2.0 \mathrm{~kg} \mathrm{~m}^{-3}$ superphosphate. The cycle of production of seedlings in the nursery lasted approximately 100 days, starting from piling up the shipment of seedlings to the field.

As an initial management of the experimental area, cleaning was carried out with the estrovenga implement, in order to remove residues from the planting lines generated by the harvest of the previous cycle. Soil preparation was performed by subsoiling at $0.60 \mathrm{~m}$ depth.

Based on the soil analysis and recommendations for eucalyptus crop based on information contained in the Manual of Fertilizer Recommendations for the State of Maranhão (ARAÚJO, 1979), liming was carried out with the application of the dose of $1.5 \mathrm{tha}^{-1}$ of dolomitic limestone, 45 days before transplanting of the seedlings. The chemical analyzes followed the methodology described in Tedesco et al. (1995). The results of the chemical analysis are shown in Table 2.

Table 2. Soil chemical attributes of the experimental area in Chapadinha, MA.

Tabela 2. Atributos químicos do solo da área do experimento em Chapadinha, MA.

\begin{tabular}{|c|c|c|c|c|c|c|c|c|c|c|c|}
\hline \multirow{2}{*}{$\begin{array}{c}\text { Layers } \\
\text { (m) }\end{array}$} & \multirow{2}{*}{$\begin{array}{c}\text { MO } \\
\left(\mathrm{g} \mathrm{dm}^{-3}\right)\end{array}$} & \multirow{2}{*}{$\begin{array}{c}P \\
\left(\mathrm{mg} \mathrm{dm}^{-3}\right)\end{array}$} & \multicolumn{6}{|c|}{ Exchangeable cations $\left(\mathrm{cmol}_{\mathrm{c}} \mathrm{dm}^{-3}\right)$} & \multirow{2}{*}{$\begin{array}{l}\text { SB } \\
(\%)\end{array}$} & \multirow{2}{*}{$\begin{array}{c}\mathrm{m} \\
(\%)\end{array}$} & \multirow{2}{*}{$\begin{array}{c}\mathbf{p H} \\
\left(\mathrm{CaCl}_{2}\right)\end{array}$} \\
\hline & & & $\mathbf{K}^{+}$ & $\mathrm{Mg}^{2+}$ & $\mathrm{Ca}^{2+}$ & $\mathrm{Al}^{3+}$ & $\mathbf{H}+\mathbf{A l}$ & CTC & & & \\
\hline $0.00-0.20$ & 12.3 & 6.8 & 0.10 & 1.1 & 1.2 & 0.2 & 6.1 & 9.4 & 22.0 & 0.3 & 5.2 \\
\hline $0.20-0.40$ & 7.6 & 2.5 & 0.07 & 0.8 & 0.7 & 0.2 & 5.5 & 7.6 & 23.7 & 2.7 & 4.4 \\
\hline $0.40-0.60$ & 5.8 & 2.9 & 0.06 & 0.5 & 0.9 & 0.5 & 5.4 & 5.8 & 27.3 & 6.1 & 4.3 \\
\hline $0.60-1.00$ & 4.1 & 3.1 & 0.07 & 0.7 & 0.8 & 0.7 & 5.0 & 5.7 & 32.8 & 6.7 & 4.5 \\
\hline
\end{tabular}

In which: $\mathrm{MO}=$ Organic matter; $\mathrm{P}=$ Phosphorus available; $\mathrm{SB}=$ Basis Saturation; $\mathrm{m}=$ Aluminum saturation. 
The first fertilization occurred in conjunction with subsoiling in soil preparation, applying $500 \mathrm{~kg} \mathrm{ha}^{-1}$ of the granulated NPK formulation $(06-30-06)+1.0 \% \mathrm{Zn}+0.3 \% \mathrm{Cu}$, in the system of continuous fillet, being fertilized the whole line of planting.

The second fertilization, or cover fertilization, was done 90 days after planting of the seedlings, applying manually in the area of projection of the canopy of each plant, $150 \mathrm{~g}$ of NPK formulation $(18-06-24)+0.7 \%$ from B. It should be noted that prior to cover fertilization, as well as during the whole experiment, weed removal was carried out through manual and chemical weeding between the lines, respectively.

The experimental design was randomized blocks, with seven treatments and three replications. Each experimental plot occupied an area of 0.2 ha, totaling 1.4 ha per block. The spacing adopted for the cultivation was $3.0 \times 2.5$ meters, and each plot consisted of 267 plants. After the selection and dispatch of the seedlings to the field, the planting stage was started, where the treatments were applied (Table 3 ).

Table 3. Appllied treatments applied in the experimental area in Chapadinha, MA.

Tabela 3. Tratamentos aplicados na área experimental em Chapadinha, MA.

\begin{tabular}{|c|c|}
\hline \multicolumn{2}{|r|}{ Tratamentos } \\
\hline T1 & Planting without the use of hidroretentor gel; \\
\hline $\mathrm{T} 2$ & Without Pre Irrigation; \\
\hline $\mathrm{T} 3$ & 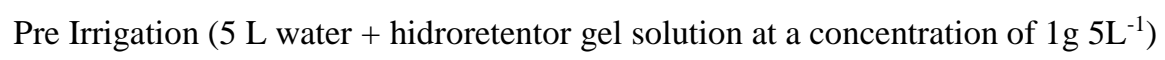 \\
\hline $\mathrm{T} 4$ & 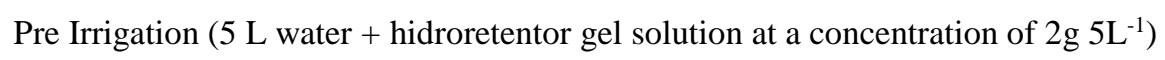 \\
\hline T5 & 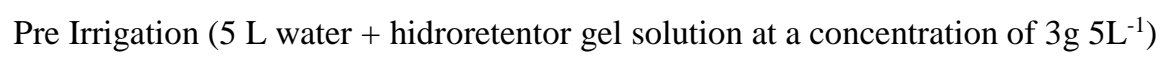 \\
\hline T6 & Pre Irrigation ( $5 \mathrm{~L}$ water + hidroretentor gel solution at a concentration of $4 \mathrm{~g}^{5 \mathrm{~L}^{-1}}$ ) \\
\hline $\mathrm{T} 7$ & 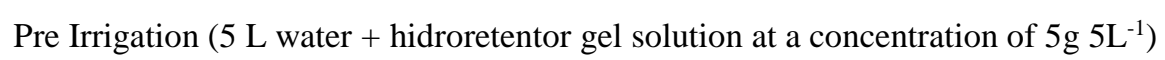 \\
\hline
\end{tabular}

The planting T1 without the use of hidroretentor gel was manually. After its placement in the pit, the soil was lightly compacted until the height of the colon, in order to avoid the formation of air pockets. On the other hand, the other treatments were carried out semi-mechanized using mats, which were coupled to a tank, with a capacity of $3.75 \mathrm{~m}^{3}$, mounted on a truck drawn by a tractor at constant speed. These opened the pits, introducing 0.5 liters of hidroretentor + water at the time of planting, in the concentration of $3 \mathrm{~g} \mathrm{~L}^{-1}$; along with the seedlings. Thirty minutes before planting the treatments from $\mathrm{T} 3$ to $\mathrm{T} 7$, they received pre-irrigation (Table 3 ), with increasing doses of gel solution + water.

In this pre-irrigation tank truck was used with coupled hoses, covering two lines simultaneously, with dosing device, which provided a volume of 5 liters of the solution per pit. The conventional system of gel addition at planting, using the ratchet, limits the volume of hidroretentor gel + water to be applied at $0.5 \mathrm{~L}$. It is emphasized that higher volumes can cause drowning of the stem, thus causing a higher mortality of the seedlings, since the gel applied in a higher concentration does not mix to the soil forming a single body (gel + water).

All plots of the experiment were irrigated twice, three days and ten days after planting by applying a volume of $4 \mathrm{~L}_{\text {plant }}{ }^{1}$.

The following variables were evaluated: survival index, plant height, stem diameter and root system depth. The survival index was determined based on the count of live plants, establishing a proportion in relation to the total number of plants expected in the useful area of the experimental unit at 30 days after planting.

The measurement of the diameters was performed at 1,30,60, 90 and 180 days after planting, and measuring the diameter with a neck day performed using a digital caliper with $0.01 \mathrm{~mm}$ resolution, and the other was using diametric tape already graduated at pi ranges $(\pi=3.1415)$, which provide direct diameter measurement. To measure plant height up to 30 days, a graduated telescopic ruler was used. From this, the measurement was performed with a clinometer, model PM5.

For the study of the root system excavations were made in fifteen plants per treatments, being five of each block, distanced in a meter, around the selected plant of random form, until the depth reached by the roots. After the excavations, a root length measurement was used to determine the depth of the roots at 180 days after planting.

The data obtained after assessments of Eucalyptus seedlings were subjected to analysis of variance and when significant, the mean comparison between treatments by Tukey's test at $5 \%$ probability of error. 


\section{RESULTS}

The treatment survival rates of the clonal seedlings of Eucalyptus grandis x E. urophylla- 03, thirty days after planting are presented in Table 4. Among the treatments applied only T1, without pre-irrigation and without the use of hidroretentor gel at the time of planting, presented value less than $95 \%(89.47 \%)$ of seedling survival.

Table 4. Survival index of Eucalyptus grandis x E. urophylla - 03 cuttings, 30 days after planting.

Tabela 4. Índice de sobrevivência das mudas clonais de Eucalyptus grandis x E. urophylla - 03, 30 dias após o plantio.

\begin{tabular}{ccc}
\hline Treatments & $\begin{array}{c}\text { Survival Index } \\
(\%)\end{array}$ \\
\hline T1 & $89.47 \mathrm{~b}$ \\
T2 & $95.61 \mathrm{a}$ \\
T3 & $97.99 \mathrm{a}$ \\
T4 & $98.62 \mathrm{a}$ \\
T5 & $99.37 \mathrm{a}$ \\
T6 & $99.12 \mathrm{a}$ \\
\hline T7 $(\%)$ & $99.25 \mathrm{a}$ \\
\hline
\end{tabular}

Means followed by the same letter in the column do not differ from each other by the Tukey test at $5 \%$ probability. CV = coefficient of variation.

Other treatments using gel showed satisfactory values (above 95\%) did not differ between them (Table 4), being possible to observe a growing trend of these indices with increasing dose applied hidroretentor gel. Visually evaluating the experimental area three days after the planting of the seedlings, before the first irrigation, it was possible to verify that the plants where the gel was used showed no symptoms of water deficit and presented superior vigor when compared to T1. The same was repeated in the second irrigation performed ten days after planting. In the first evaluation of the seedlings, one day after planting, there was no difference between treatments, in relation to diameter of the lap and height of seedlings respectively (Table 5).

Table 5. Diameter of the lap and height of Eucalyptus grandis x E. urophylla-03 plants after planting.

Tabela 5. Diâmetro de colo e altura das plantas de Eucalyptus grandis x E. urophylla - 03, após o plantio.

\begin{tabular}{|c|c|c|c|c|c|}
\hline \multirow{3}{*}{ Treatments } & \multicolumn{5}{|c|}{ Time (days) } \\
\hline & 1 & 30 & 60 & 90 & 180 \\
\hline & \multicolumn{5}{|c|}{ Diameter of the lap $(\mathrm{cm})$} \\
\hline $\mathrm{T} 1$ & $0.35 \mathrm{a}$ & $0.60 \mathrm{~b}$ & $0.75 \mathrm{~d}$ & $1.50 \mathrm{~d}$ & $2.26 \mathrm{c}$ \\
\hline $\mathrm{T} 2$ & $0.35 \mathrm{a}$ & $0.90 \mathrm{a}$ & $1.17 \mathrm{c}$ & $2.35 \mathrm{c}$ & $3.14 \mathrm{~b}$ \\
\hline T3 & $0.36 \mathrm{a}$ & $0.90 \mathrm{a}$ & $1.17 \mathrm{c}$ & $2.35 \mathrm{c}$ & $3.15 \mathrm{~b}$ \\
\hline $\mathrm{T} 4$ & $0.35 \mathrm{a}$ & $0.92 \mathrm{a}$ & $1.16 \mathrm{c}$ & $2.38 \mathrm{bc}$ & $3.15 \mathrm{~b}$ \\
\hline $\mathrm{T} 5$ & $0.35 \mathrm{a}$ & $0.93 \mathrm{a}$ & $1.28 \mathrm{~b}$ & $2.41 \mathrm{~b}$ & $3.17 \mathrm{~b}$ \\
\hline T6 & $0.36 \mathrm{a}$ & $0.95 \mathrm{a}$ & $1.37 \mathrm{a}$ & $2.53 \mathrm{a}$ & $3.39 \mathrm{a}$ \\
\hline $\mathrm{T} 7$ & $0.34 \mathrm{a}$ & $0.97 \mathrm{a}$ & $1.37 \mathrm{a}$ & $2.53 \mathrm{a}$ & $3.39 \mathrm{a}$ \\
\hline \multirow[t]{2}{*}{$\mathrm{CV}(\%)$} & 6.98 & 7.04 & 4.33 & 5.34 & 6.17 \\
\hline & \multicolumn{5}{|c|}{ Height of plants (m) } \\
\hline $\mathrm{T} 1$ & $0.28 \mathrm{a}$ & $0.40 \mathrm{c}$ & $0.46 \mathrm{f}$ & $0.78 \mathrm{e}$ & $2.35 \mathrm{e}$ \\
\hline $\mathrm{T} 2$ & $0.28 \mathrm{a}$ & $0.56 \mathrm{~b}$ & $0.65 \mathrm{e}$ & $1.24 \mathrm{~d}$ & $3.22 \mathrm{~d}$ \\
\hline T3 & $0.28 \mathrm{a}$ & $0.57 \mathrm{~b}$ & $0.70 \mathrm{~d}$ & $1.25 \mathrm{~d}$ & $3.27 \mathrm{~cd}$ \\
\hline $\mathrm{T} 4$ & $0.28 \mathrm{a}$ & $0.60 \mathrm{~b}$ & $0.75 \mathrm{c}$ & $1.29 \mathrm{c}$ & $3.32 \mathrm{bc}$ \\
\hline T5 & $0.27 \mathrm{a}$ & $0.67 \mathrm{a}$ & $0.78 \mathrm{~b}$ & $1.39 \mathrm{~b}$ & $3.38 \mathrm{~b}$ \\
\hline T6 & $0.28 \mathrm{a}$ & $0.69 \mathrm{a}$ & $0.83 \mathrm{a}$ & $1.43 \mathrm{~b}$ & $3.49 \mathrm{a}$ \\
\hline $\mathrm{T} 7$ & $0.28 \mathrm{a}$ & $0.69 \mathrm{a}$ & $0.82 \mathrm{a}$ & $1.58 \mathrm{a}$ & $3.53 \mathrm{a}$ \\
\hline $\mathrm{CV}(\%)$ & 5.01 & 6.04 & 6.39 & 8.89 & 7.23 \\
\hline
\end{tabular}

Means followed by the same letter in the column do not differ from each other by the Tukey test at 5\% probability. $\mathrm{CV}=$ coefficient of variation. 
Regarding the diameter of the lap, at 30 days after planting, it is possible to observe a difference between the treatments submitted to the gel doses, when compared to the treatment without addition of gel at the time of planting (Table 5). It was not possible to identify, at 30 days, a dose of hidroretentor gel that allowed greater growth of the diameter of the plants in the field, since they did not differ. The highest averages found are in T7, where they present an average value of 0.97 centimeters, while in the absence of gel application the averages were concentrated in average values of 0.60 centimeters.

With respect to the height (Table 5), the observed behavior was similar to the diameter of the lap. Treatments submitted to the doses of gel presented superior development to the treatment without gel in its implantation. Treatments 5, 6 and 7 showed the best results, with 0.67; 0.69 and 0.69 meters respectively, 30 days after planting. These differences between treatments with and without hidroretentor gel were visible mainly because in the first thirty days the region presented low rainfall index (Figure 1), highlighting the volume of water that the gel was able to retain and make available to the plants in its phase establishment critic in the field.

At 60 days after planting, the diameter of the lap continued to show differences between treatments with and without hidroretentor gel, highlighting treatments 6 and 7, with values of $1.37 \mathrm{~cm}$. The same occurred for the plant height variable, which after the same period presented a difference between the treatments with and without the hidroretentor, and of the treatments with polymer application were the T6 and T7 with 0.83 and 0 , respectively, $82 \mathrm{~m}$.

Based on the results we can observe the tendency of plants with higher initial development both in height and diameter of the lap, in this case justified by application of hidroretentor polymer. At 90 days after planting the seedlings in the field the treatments submitted to increasing doses of gel present a difference when compared to the treatment without using the gel (Table 5).

In the last evaluation, 180 days after the planting of the seedlings, the growth in height still presented differences between the treatments, being that the treatment 1 , without addition of hidroretentor gel, provided a worse result $(2.5 \mathrm{~m})$, and the best treatments were 6 and 7 with 3.49 and $3.53 \mathrm{~m}$ respectively (Table 5). With respect to the diametrical growth, it was possible to divide the results into three groups, with treatment 1 with the worst results $(2.26 \mathrm{~cm})$ and treatments 6 and 7 with better results $(3.39 \mathrm{~cm})$.

The results obtained allow us to infer that higher doses of hydrogel favor the development of the culture. This is possibly due to the fact that there is more water retention in the presence of higher doses of hydrogel and, therefore, more water available to the plant.

For the results relating to the length of the root system at 180 days (Table 6) is observed that treatment 1 was superior to the others with an average of $1.43 \mathrm{~m}$. This information leads us to infer that larger doses of gel limit the initial development of the root system. On the other hand, the plants that developed without the use of the hidroretentor gel created mechanisms to deepen its root system in search of water and nutrients.

Table 6. Length of root system of Eucalyptus grandis x E. urophylla-03 plants, 180 days after planting.

Tabela 6. Comprimento do sistema radicular de plantas de Eucalyptus grandis x E. urophylla - 03, 180 dias após o plantio.

\begin{tabular}{cc}
\hline Treatments & Length of root (m) \\
\hline $\mathrm{T} 1$ & $1.43 \mathrm{a}$ \\
$\mathrm{T} 2$ & $1.27 \mathrm{~b}$ \\
$\mathrm{~T} 3$ & $1.26 \mathrm{~b}$ \\
$\mathrm{~T} 4$ & $1.27 \mathrm{~b}$ \\
$\mathrm{~T} 5$ & $1.16 \mathrm{~b}$ \\
$\mathrm{~T} 6$ & $1.17 \mathrm{~b}$ \\
$\mathrm{~T} 7$ & $1.13 \mathrm{~b}$ \\
\hline $\mathrm{CV}(\%)$ & 7.86 \\
\hline
\end{tabular}

Means followed by the same letter in the column do not differ from each other by the Tukey test at 5\% probability. CV = coefficient of variation. 


\section{DISCUSSION}

In commercial eucalyptus plantations for cellulose and energy (coal and firewood), it is recommended that the survival rates per crop area should be higher than $95 \%$, a value higher than that found in the present study for the treatments with application of hydrogel, showing that regardless of dosage, adequate survival rates are achieved, but if they present lower values, as observed in $\mathrm{T} 1$, it is believed that problems occurred during the implantation of the crop, which cause production losses at the end of the cycle. This index is of great importance for decision making in cases of replanting, because, based on these values, the operational cost of carrying out this operation is evaluated.

Felício et al. (2016) found that visually increasing polymer dose caused water retention by a larger time interval, reducing premature mortality of eucalyptus seedlings. Likewise, Buzetto et al. (2002) and Navroski et al. (2014), also verified this positive effect of hydrogel in post-planting of Eucalyptus dunnii. According to Bartieres et al. (2016), the use of the hydrogel alone does not favor the growth of the plants, however it increases the survival when compared to the control treatment, without hydrogel or additional fertilization. These results differed from those of Saad et al. (2009), in which the use of hydrogel did not result in increased plant survival in both sandy and sandy soils.

As for irrigation, in the presence of the polymer, Navroski et al. (2014) verified that the frequency of six days shows a good gain without the appearance of symptoms as the initial wilt, characterized by wilting of the apex and curving of some leaves. At this point of stress, the plants are able to recover in the presence of rain. Not using the polymer, even with irrigation there is an accelerated occurrence of these symptoms. In more frequent irrigations (three days) the appearance of mild wilt symptoms occurred in relatively high time, both in the presence and absence of the polymer. However, it should be considered that frequent irrigations require greater financial resources and also availability of water near the planting site.

The results of the present study are of great relevance, since it has shown that seedlings with higher heights and diameter of the lap develop more rapidly than changes in height and smaller diameters. Therefore, in order to minimize the errors caused by this difference in height, we sought to acquire a lot with more uniform seedlings possible. In addition, plants with higher initial development both in height and in diameter of colon were observed, in this case justified by the application of the hidroretentor polymer, which is related to two factors, the first factor being related to the initial growth of these plants in the field, where the plants that did not suffer with water deficit were able to develop better initially both in height and in diameter of lap, and with this leading to this favorable condition provided in the establishment of the seedlings at the moment of planting for the following months becoming more and more evident the influence of plant diameter and height at the early stage of eucalyptus planting.

The second factor that may be related to the difference presented between the treatments, providing a better development to which larger doses of gel were applied is conditioned to the residual effect of this product in the soil, which according to the manufacturers can stay present in the soil up to six months after the application, thus making better use of the precipitations that occurred in the region.

Lopes et al. (2010) observed that the use of $0.96 \mathrm{~g}$ of hydrated polymer in the pit allowed the maintenance of the water potential of Eucalyptus urograndis seedlings in up to 37 days of water restriction, without compromising growth. These variables are important for selection and establishment of seedlings in the field, leading to a higher performance of these seedlings. According to José et al. (2009), the measures of diameter and height are the main characteristics for selection of seedlings for planting.

Demonstrating the beneficial effect of the hidroretentor gel in the initial phase of cultivation, corroborating with Binotto et al. (2010), which indicate, among the evaluated variables, the diameter of the lap as the most favorable parameter to indicate quality of seedlings. According to Fonseca et al. (2002), the shoot height/shoot diameter ratio should be used in conjunction with other parameters in determining the best seedling quality standard.

The results showed that the seedlings continue to present the following months better development, a result consistent with evidenced by Gomes et al. (2002), this result is important since according to Rossa et al. (2015) height is an important feature when there is a need to plant seedlings in areas colonized by weeds, where the height of the species of interest leads to greater competition for light, yet these characteristics are considered for establishing the value of seedlings (GOMES et al., 2002).

Observing the other results, it is possible to verify the tendency to decrease the differences between the analyzed variables over the months, this observation is in agreement with what was observed by José et al. (2005) who, working with Schinus terebinthifolius (aroeira), verified that initial differences in height and diameter of seedlings tend to disappear over time in the field.

FLORESTA, Curitiba, PR, v. 49, n. 3, p. 391-400, jul/set 2019. 
The results obtained allow us to infer that higher doses of hydrogel favor a better development of the culture. This is possibly due to the fact that there is more water retention in the presence of higher doses of hydrogel and, therefore, more water available to the plant.

The results obtained in this work are in agreement with Mendonça et al. (2013) who tested different doses of hydrogel in Dystrophic Red Latosol (in pots) and obtained an increase in water storage capacity. The treatment of $4 \mathrm{~g}$ per vessel (8L) increased the storage capacity of water in the soil by $12 \%$ compared to the control, while by applying twice the product ( $8 \mathrm{~g}$ per pot), the increase in relation to the control was $13 \%$. Koupai et al. (2008) found significantly higher water retention values in treatments that received hydrogels compared to the non-hydrogel treatment, also giving hydrogel treatments higher values of available water content for the plants.

Navroski et al. (2016) also observed that dosages above $100 \%$ caused a decrease in dry mass, both aerial and root. It was possible to show a large amount of secondary and tertiary roots present in the treatments submitted to the gel, but in treatment 1 the roots presented smaller volume despite being identified in greater depth. Huttermann et al. (1999) also observed a greater development of the culture in the presence of hydrogel, especially of the root system, that presented greater volume of roots. This information leads us to infer that larger doses of gel limit the initial development of the root system, in contrast to the plants that developed without the use of the hidroretentor gel, they created mechanisms to deepen their system in search of water and nutrients.

Navroski et al. (2015) reported that the dry root mass has good response to the use of the hydrogel and that the highest dose provides greater root mass, probably due to the greater availability of water and nutrients. However, this did not reflect the increase in other variables, such as height, diameter of the collection result that differs from this work. According to Eloy et al. (2013), this variable presents significant importance in the development of plants, because when they are well rooted, they present greater growth capacity and greater potential for survival in the field.

Corroborating with these results Nicoletti et al. (2014), studying the effect of this polymer on the rooting and initial growth of minicuttings of the Eucalyptus urograndis x E. grandis hybrid, the root dry mass showed good response to the use of the same. Similar result found by Felippe et al. (2016), in the root dry mass when compared to the absence in the use of this polymer for the species Eucalyptus benthamii.

This positive effect of the polymer on the root system becomes important, since, Vogt and Persson (1991), root growth can be responsible for up to $50 \%$ of the local primary productivity, becoming, therefore, one of the main paths through which carbon enters the soil, being essential for the continuity and stability of the microbiota and for the cycling of nutrients in the forest ecosystem.

\section{CONCLUSIONS}

- The use of pre-irrigation enhances the growth of post-planting eucalyptus seedlings, providing the best establishment in the field.

- The application of hidroretentores polymers, known as a hidroretentor gel, in the concentration of 4 and $5 \mathrm{~g}$ $5 \mathrm{~L}^{-1}$, provides a higher height and diameter of lap planting eucalyptus seedlings.

- The depth of the root system does not increase when a larger dose of gel is used, presenting lower values than those obtained by the treatment without the use of the hidroretentor gel.

\section{REFERENCES}

BARTIERES, E. M. M.; CARNEVALI, N. H. S.; LIMA, E. S.; CARNEVALI, T. O.; MALLMANN. Hidrogel, calagem e adubação no desenvolvimento inicial, sobrevivência e composição nutricional de plantas híbridas de eucalipto. Pesquisa Florestal Brasileira, Colombo, v. 36, n. 86, p. 145-151, 2016.

BINOTTO, A. F.; LÚCIO, A. D.; LOPES, S. J. Correlations between growth variables and the dickson quality índex in forest seedlings. Cerne, Lavras, v. 16, n. 4, p. 457-464, 2010.

BUZETTO, F. A.; BIZON, J. M. C.; SEIXAS, F. Avaliação de polímero adsorvente à base de acrilamida no fornecimento de água para mudas de Eucalyptus urophylla em pós-plantio. 2002. Disponível em: http://www.ipef.br/publicacoes/ctecnica/nr195.pdf>. Acesso em: 07 agosto 2017.

ELOY, E.; CARON, B. O.; SCHMIDT, D.; BEHLING, A.; SCHWERS, L.; ELLI, E. F. Avaliação da qualidade de mudas de Eucalyptus grandis utilizando parâmetros morfológicos. Revista Floresta, Curitiba, v. 43, n. 3, p. $373-384,2013$. 
EMBRAPA. Sistema brasileiro de classificação dos solos. Rio de Janeiro: Embrapa CNPS, 2013, 412p.

FELÍCIO, R.; CUSTÓDIO, I. C.; OLIVEIRA, J. P. M.; SILVEIRA, P. S.; MATOS, F. S. Crescimento inicial de eucalipto acondicionadas com hidrogel e submetidas ao déficit hídrico. Revista Agrotecnologia, Ipameri, v. 7, n. 1, p. 18-26, 2016.

FELIPPE, D.; NAVROSKI, M. C.; SAMPIETRO, J. A.; FRIGOTTO, T.; ALBUERQUERQUE, J. A.; MOTA, C. S.; PEREIRA, M. O. Efeito do hidrogel no crescimento de mudas de Eucalyptus benthamii submetidas a diferentes frequências de irrigação. Revista Floresta, Curitiba, PR, v. 46, n. 2, p. 215 - 225, 2016.

FERREIRA, E. A.; SILVA, V. A.; SILVA, E. A.; SILVEIRA, H. R. O. Eficiência do hidrogel e respostas fisiológicas de mudas de cultivares apirênicas de citros sob défice hídrico. Pesquisa Agropecuária Tropical, Goiânia, v. 44, n. 2, p. 158-165, 2014.

FONSECA, E. P.; VALÉRI, S. V.; MIGLIORANZA, E.; FONSECA, N. A. N.; COUTO, L. Padrão de qualidade de mudas de Trema micrantha (L.) Blume. Produzidas sob diferentes períodos de sombreamento. Revista Árvore. Viçosa, v. 26, n. 4, p. 515-523, 2002.

GOMES, J. M.; COUTO, L.; LEITE, H. G.; XAVIER, A.; GARCIA, S. L. R. Parâmetros morfológicos na avaliação da qualidade de mudas de Eucalyptus grandis. Revista Árvore, Viçosa, v. 26, n. 6, p. 655-664, 2002.

HUTTERMANN, A. ZOMMORODI, M.; REISE, K. Addition of hydrogels to soil for prolonging the survival of Pinus halepensis seedlings subjected to drought. Soil and Tillage Research, Amsterdam, v. 50, n. 3-4, p. 295304, 1999.

JOSÉ, A. C.; DAVIDE, A. C.; OLIVEIRA, S. L. Efeito do volume do tubete, tipo e dosagem de adubo na produção de mudas de aroeira (Schinus terebenthifolia RADDI). Agrarian, Dourados, v. 2, n. 3, p.73-86, 2009.

JOSÉ, A. C.; DAVIDE, A. C.; OLIVEIRA, S. L. Produção de mudas de aroeira (Schinus terebinthifolius Raddi) para recuperação de áreas degradadas pela mineração de bauxita. Cerne, Lavras, v. 11, n. 2, p.187-196, 2005.

KOUPAI, J. A.; ESLAMIAN, S. S.; KAZEMI, J. A. Enhancing the available water content in unsaturated soil zone using hydrogel, to improve plant growth indices. Ecohydrology and Hydrobiology, Poland, v. 8, n. 1, p. 67-75, 2008.

LOPES, J. L. W.; SILVA, M. R.; SAAD, J. C. C.; ANGÉLICO, T. S. Uso de hidrogel na sobrevivência de mudas de Eucalyptus urograndis produzidas com diferentes substratos e manejos hídricos. Ciência Florestal, Santa Maria, v. 20, n. 2, p. 217 - 224, 2010.

MENDONÇA, T. G.; URBANO, V. R.; PERES, J. G.; SOUZA, C. F. Hidrogel como alternativa no aumento da capacidade de armazenamento de água no solo. Water Resources and Irrigation Management, Cruz das Almas, v. 2, n. 2, p. 87-92, 2013.

NAVROSKI, M. C.; ARAÚJO, M. M.; CUNHA, F. S.; BERGHETTI, A. L. P.; PEREIRA, M. O. Redução da adubação e melhoria das características do substrato com o uso do hidrogel na produção de mudas de eucalyptus dunnii Maiden. Ciência Florestal, Santa Maria, v. 26, n. 4, p. 1155-1165, 2016.

NAVROSKI, M. C.; ARAÚJO, M. M.; REININGER, L. R. S.; MUNIZ, M. F. B.; PEREIRA, M. O. Influência do hidrogel no crescimento e no teor de nutrientes das mudas de Eucalyptus dunnii. Revista Floresta, Curitiba, v. 45, n. 2, p. $315-328,2015$.

NAVROSKI, M. C.; ARAÚJO, M. M.; CUNHA, F. S.; BERGHETTI, A. L. P.; PEREIRA, M. O. Influência do polímero hidroretentor na sobrevivência de mudas de Eucalyptus dunnii sob diferentes manejos hídricos. Revista Nativa, Sinop, v. 2, n. 2, p. 108 - 113, 2014.

NICOLETTI, M. F; NAVROSKI, M. C.; ANDRIOLLO, K.; PEREIRA, M. O.; FRIGOTTO, T. Efeito do hidrogel no enraizamento e crescimento inicial de miniestaca do híbrido Eucalyptus urograndis. Cultivando o Saber, Cascavel, v. 7, n. 4, p. 353 - 361, 2014.

ROSSA, U. B.; ANGElO, A. C.; WESTPHALEN, D. J.; OlIVEIRA, F. E. M.; SILVA, F. F.; ARAUJO, J. C. Fertilizante de liberação lenta no desenvolvimento de mudas de Anadenanthera peregrina (1.) speg. (Angicovermelho) e Schinus terebinthifolius Raddi (Aroeira-vermelha). Ciência Florestal, Santa Maria, v. 25, n. 4, p. 841-852, 2015.

FLORESTA, Curitiba, PR, v. 49, n. 3, p. 391-400, jul/set 2019.

Bernardino, L. T. et.al.

ISSN eletrônico 1982-4688

DOI: $10.5380 /$ rf.v49 i3.56245 
SAAD, J. C. C.; LOPES, J. L. W.; SANTOS, T. A. Manejo hídrico em viveiro e uso de hidrogel na sobrevivência pós-plantio de Eucalyptus urograndis em dois solos diferentes. Engenharia Agrícola, Jaboticabal, v. 29, n. 3, p. 404 - 411, 2009.

SOUZA, L. R.; PERES, F. S. B. Uso de biofertilizantes à base de aminoácidos na produção de mudas de Eucalyptus dunnii. Pesquisa Florestal Brasileira, Colombo, v. 36, n. 87, p. 211-218, 2016.

TEDESCO, M. J.; GIANELLO, C.; BISSANI, C.A.; BOHNEN, H.; VOLKWEISS, S.J. Análise de solo, plantas e outros materiais. 2.ed. Porto Alegre, Departamento de Solos da Universidade Federal do Rio Grande do Sul. 1995. 174p. (Boletim Técnico de Solos, 5)

VOGT, K. A., PERSSON, H. Measuring growth and development of roots. In Lassoie., J. P., Hinckley, T. M. (Eds.). Techniques and Approaches in Forest Tree Ecophysiology. CRC Press, Boca Raton, p. 447-501, 1991. 